\title{
Review \\ Depression, Antidepressants, and Neurogenesis: A Critical Reappraisal
}

\author{
Nicola D Hanson', Michael J Owens*,' and Charles B Nemeroff ${ }^{2}$ \\ 'Laboratory of Neuropsychopharmacology, Department of Psychiatry and Behavioral Sciences, Emory University School of Medicine, \\ Atlanta, GA, USA; 'Department of Psychiatry and Behavioral Sciences, University of Miami School of Medicine, Miami, FL, USA
}

\begin{abstract}
The neurogenesis hypothesis of depression posits (I) that neurogenesis in the subgranular zone of the dentate gyrus is regulated negatively by stressful experiences and positively by treatment with antidepressant drugs and (2) that alterations in the rate of neurogenesis play a fundamental role in the pathology and treatment of major depression. This hypothesis is supported by important experimental observations, but is challenged by equally compelling contradictory reports. This review summarizes the phenomenon of adult hippocampal neurogenesis, the initial and continued evidence leading to the development of the neurogenesis hypothesis of depression, and the recent studies that have disputed and/or qualified those findings, to conclude that it can be affected by stress and antidepressants under certain conditions, but that these effects do not appear in all cases of psychological stress, depression, and antidepressant treatment.
\end{abstract}

Neuropsychopharmacology (20II) 36, 2589-2602; doi: I0.1038/npp.20II.220; published online 21 September 20II

Keywords: neurogenesis; dentate gyrus; neurotrophic factors; stress; depression; antidepressant

\section{INTRODUCTION}

It is by now well understood that prolonged or intense stress can have physiologically deleterious effects on the brain. These effects, which are especially pronounced in the hippocampus, include neuronal atrophy, neurotoxicity, and neuroendangerment (making neurons more susceptible to other insults) (Sapolsky, 1996). They are largely linked to elevated concentrations of glucocorticoids, through multiple mechanisms that are still not entirely clear. Glucocorticoids in the hippocampus seem to serve an allostatic regulation function, alternately facilitating and protecting against damaging effects of excitatory aminoacid neurotransmitters to maintain stability in response to changing conditions (McEwen, 2001; Lee et al, 2002). Glucocorticoids also play important roles in better-characterized hippocampal processes, such as the modulation of neuronal excitability involved in learning and memory. Other molecular conduits, including serotonin (5-HT) and NMDA receptors, have also been implicated in stress-induced hippocampal damage.

\footnotetext{
*Correspondence: Dr MJ Owens, Laboratory of Neuropsychopharmacology, Department of Psychiatry and Behavioral Sciences, Emory University School of Medicine, 100 Woodruff Circle, Suite 4000, Atlanta, GA 30322, USA. Tel: + I 404727 4059, Fax: + | 404727 3233, E-mail: mowens@emory.edu

Received 5 May 2011; revised 15 August 201 I; accepted 19 August 2011
}

These detrimental influences of stress on the general neuronal health and plasticity in the hippocampus extend to the regulation of granule cell generation in that region. For the vast majority of the twentieth century, neurobiology was dogmatic in the belief that neurogenesis does not occur during adulthood in the mammalian brain. The first evidence of newly generated central nervous system (CNS) neurons in adulthood was reported in 1965, when Altman and Das (1965) used ${ }^{3} \mathrm{H}$-thymidine to label proliferating cells in the subgranular zone (SGZ) of the rat dentate gyrus. The resulting daughter cells became morphologically identical to mature granule cells; later studies confirmed that these new cells were indeed neurons (Kaplan and Hinds, 1977). The presence of the highly polysialated form of neural cell adhesion molecule (PSA-NCAM or NCAM-H), which is only found in immature neurons, provided additional evidence that neurogenesis occurs in the adult dentate gyrus (Seki and Arai, 1993). The existence of adultgenerated neurons in the human hippocampus was demonstrated some years later (Eriksson et al, 1998).

In addition to the adult neurogenesis seen in the dentate gyrus, the subventricular zone (SVZ) of the lateral ventricle is now known to be a second site of adult neurogenesis. Neuroblasts produced in this region travel along the rostral migratory stream to differentiate into interneurons of the olfactory bulb (reviewed in Garcia-Verdugo et al, 1998). However, unlike nascent hippocampal neurons, these cells are largely unresponsive to stress or psychoactive drugs, with the exceptions of a few reports of increased neurogen- 
esis by atypical antipsychotic drugs (Wakade et al, 2002; Green et al, 2006; Nasrallah et al, 2010). Thus, neurogenesis of the SVZ will not be addressed further in this review. In addition, some reports show a small number of adultgenerated GABAergic interneurons in the neocortex of rodents and non-human primate, although negative reports regarding this region are equally as compelling (reviewed in Cameron and Dayer, 2008). Moreover, strong evidence exists that this is unlikely to occur in humans (Bhardwaj et al, 2006). Figure 1 shows areas of adult neurogenesis in the rat brain.

\section{TIMELINE AND MARKERS OF HIPPOCAMPAL NEUROGENESIS}

The SGZ of the dentate gyrus contains Type-1 radial-glialike stem cells, which express the astrocytic marker glial fibrillary acidic protein (GFAP) as well as the intermediate filament protein nestin (Seri et al, 2001). Their population size and proliferation rate are relatively constant; these are likely the true stem cells of the region (Kempermann et al, 2004; Zhao et al, 2008; Bonaguidi et al, 2011). These cells exhibit morphology of radial glia and divide asymmetrically, producing a Type-2 daughter cell, while maintaining the parent Type- 1 cell. Type- 2 and, later, Type- 3 cells are GFAP-negative and much more proliferative than Type-1 cells, and their proliferation rates are acutely variable. Type2 cells express nestin and, as they develop, the microtubuleassociated protein doublecortin (DCX) and the polysialated form of neural cell adhesion molecule (PSA-NCAM). Type-3 cells continue to express DCX, but no longer express nestin (Encinas et al, 2006). Type-3 cells are generally referred to as neuroblasts, while Type- 2 cells are called lineage-determined progenitor cells or neural progenitor cells (NPCs). During the Type-3 stage, cells shift the orientation of new processes from horizontal (parallel to the granule cell layer) to vertical (perpendicular) and begin radial migration into the granule cell layer (Encinas et al, 2006). When the maturing cell exits the cell cycle, about 3 days after the original division, it reaches the Type- 4 cell stage. These immature granule cells begin to express the calciumbinding protein calretinin and neuronal nuclei protein (NeuN), and project axons toward the CA3 region. Survival

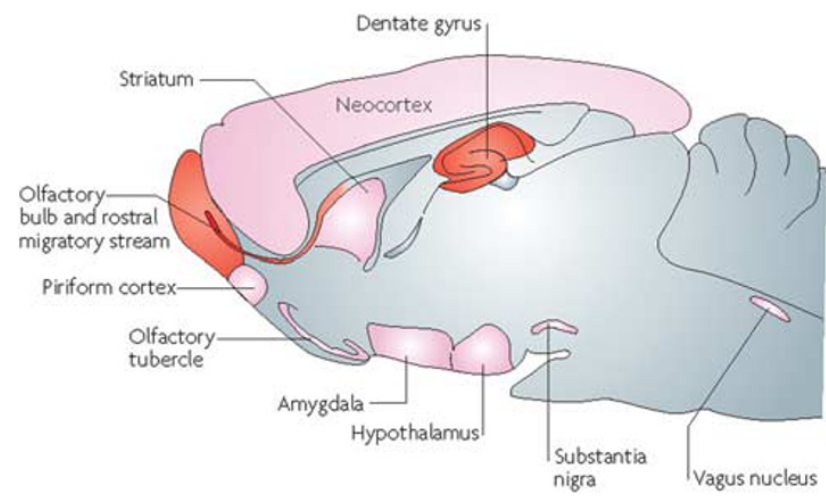

Figure I Areas of neurogenesis in the adult rat brain. Red - confirmed neurogenesis; pink - possible neurogenesis. (reproduced from Gould, 2007). of the newborn cell population is largely regulated during this stage via variable rates of apoptosis (Zhao et al, 2008). Approximately 2-3 weeks after exiting the cell cycle, they cease expressing calretinin and instead express calbindin, a marker of mature granule cells (Kempermann et al, 2004). At this point, the new neurons enter a critical period of enhanced synaptic plasticity in which their electrophysiological properties resemble those of neurons in the classic early postnatal critical period in juvenile animals (Ge et al, 2007). This phase occurs approximately 4-6 weeks after the original cell division, resulting in a total of up to 7 weeks required for newborn cells to become functionally indistinguishable from the older granule cell population (Zhao et al, 2008). Figure 2 shows the stages of neurogenesis within the dentate gyrus.

Dividing cell populations have traditionally been studied using nucleotide analogs: originally ${ }^{3} \mathrm{H}$-thymidine, and later bromodeoxyuridine (BrdU) or, less often, iododeoxyuridine or chlorodeoxyuridine. When made available via systemic injection, these molecules are incorporated into replicating DNA in place of thymidine, resulting in labeled cells that can be visualized using autoradiography or immunocytochemistry. Some concerns have been raised that BrdU might have cytotoxic effects or otherwise disrupt normal proliferation or maturation processes, but no deleterious actions of BrdU at doses well above those commonly used in labeling protocols have been shown (Hancock et al, 2009). One notable disadvantage of BrdU is that it only labels cells that are in the S-phase of the cell cycle (when DNA replication occurs). BrdU is metabolized and/or excreted within approximately $2 \mathrm{~h}$ following injection. Because progenitor cells in the dentate gyrus have been determined to have a cell cycle time of $24.7 \mathrm{~h}$ (Cameron and McKay, 2001), only a portion of the entire population of cycling cells

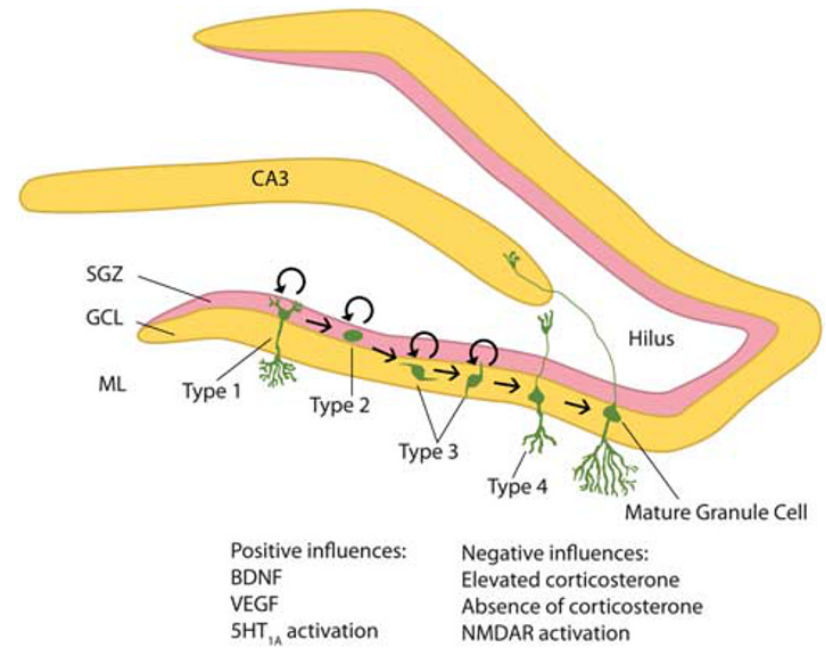

Figure 2 Stages of neurogenesis in the dentate gyrus. Type-I cells (radial-glia-like stem cells) in the subgranular zone divide asymmetrically, maintaining their population while producing Type-2 daughter cells (neural progenitor cells). These continue to divide symmetrically as they mature into Type- 3 cells (neuroblasts) and migrate into the granule cell layer. Type4 cells, which have ceased mitosis, extend axons toward the CA3, leading to the development of mature granule cells that integrate with the mossy fiber pathway. SGZ, subgranular zone; GCL, granule cell layer; ML, molecular layer. 
is labeled. Although changes in the number of BrdU-labeled cells accurately represent changes in the total number of currently cycling cells, a single pulse will not yield an estimate of the true total cycling population. Many investigators attempt to solve this problem by using repeated pulses, maintaining BrdU availability over at least a full cell cycle. However, because BrdU-labeled DNA is passed on to daughter cells, this adds the complication of allowing those cells labeled early in the availability period to complete mitosis following labeling, resulting in doubling of the labeled cell number. In contrast, those labeled late in the period will not have time to complete mitosis and will only result in single labeled cells. This distorts the makeup of the targeted cell population, confounding interpretation of the results. The number of cells labeled by a single pulse of a nucleotide analog peaks at 1 week, marking the shift of most of the population from the proliferative Type- 2 and -3 stages to the nonproliferative Type-4, at which time cells are subjected to a high rate of apoptosis. At 4 weeks post-labeling, virtually all labeled cells in the granule cell layer express neuronspecific enolase, identifying them as mature neurons; the small number that express GFAP are likely Type-1 progenitor cells (Cameron et al, 1993b).

In recent years, the endogenous protein marker Ki-67 has emerged as an alternative target for the labeling of proliferating cells. This protein is expressed in the nucleus during all phases of the cell cycle, although its function is unclear (Kee et al, 2002). It can be easily visualized using immunocytochemistry and eliminates the issues surrounding incorporation periods, as well as any stress associated with injection procedures. Because staining for Ki-67 identifies all cycling cells, rather than only those currently in the S-phase, counts of Ki-67-labeled cells are approximately twofold higher than BrdU-labeled cells in the same experimental situation. However, relative expression patterns of Ki-67 and BrdU incorporation have been found to be highly correlated under a number of conditions, validating the use of either method according to convenience. It is common to study multiple stages of the neurogenic process in a single animal by injecting BrdU 3-4 weeks before being killed to identify long-term cell survival, and also labeling Ki-67, DCX, nestin, or other markers to examine particular stages of proliferation and development.

\section{IMPORTANCE OF NEUROGENESIS IN HIPPOCAMPAL FUNCTION}

The number of granule cell neurons generated each month in the dentate gyrus is approximately $6 \%$ of the total population (Cameron and McKay, 2001). The magnitude of this continuous production of new neurons indicates that they play an important role in hippocampal function, for which several possible hypotheses have been proposed. Computational network theories suggest that new neurons lend advantages in the temporary storage and processing of new memories (Deisseroth et al, 2004; Wiskott et al, 2006). It has repeatedly been reported that young granule cells display characteristics very different from mature ones, such as reduced threshold to induction of long-term potentiation (LTP) and an excitatory response to GABAergic input (Wang et al, 2000; Snyder et al, 2001; $\mathrm{Ge}$ et al, 2006). In fact, calcium signaling resulting from the activation of GABA receptors has been found to promote activity-dependent differentiation and regulate synaptic integration of these neuronal precursor cells (Tozuka et al, 2005; Ge et al, 2006).

A large body of literature supports a bidirectional relationship between learning and neurogenesis. Participation in learning tasks, particularly those involving hippocampal-dependent spatial memory formation (ie, place recognition or maze tasks) or exposure to enriched or novel environments, which facilitate spatial learning, are associated with increased rates of hippocampal neurogenesis (Leuner et al, 2006). The most compelling arguments indicate a specific role in spatial pattern separation: mice subjected to site-specific $\mathrm{x}$-ray irradiation to ablate hippocampal cell proliferation develop significant impairment in the low spatial separation component of a challenging memory task, but function normally when presented with larger spatial separations and in other tasks of general spatial learning and memory (Clelland et al, 2009). Others report that the same irradiation treatment produces mice with normal spatial learning in the Morris water maze, but impairments in the Barnes maze, which requires distinguishing a single escape tunnel from 40 possible locations and necessitates finer spatial separation assessment than the Morris maze (Raber et al, 2004). (Any discussion of experimental ablation of neurogenesis via $\mathrm{x}$-ray irradiation must mention that this method has an important drawback: it is not possible to control for other, non-neurogenic effects of the treatment. More details on hippocampal irradiation are included in the section 'The neurogenesis hypothesis of depression' below.) Interestingly, rats that primarily use a hippocampus-dependent place strategy in the Morris water maze exhibit lower rates of NPC proliferation than those rats, which use a nonhippocampus-dependent cue strategy, although they do not differ in survival rates of newborn neurons (Epp and Galea, 2009).

There is a compelling body of evidence that young granule cells are more responsive than their older counterparts to learning involving fear or anxiety. Survival and fos-activation within young granule cells are increased in animals exposed to a Morris water maze, but not in swim controls, which experience the stressful condition of the swim without the spatial learning component of hidden platforms (Gould et al, 1999; Snyder et al, 2009). In addition, inhibition of hippocampal neurogenesis using $\mathrm{x}$-ray irradiation showed that the presence of immature neurons at the time of training is required for learning in the water maze (Snyder et al, 2005). Context-dependent fear conditioning also seems to be neurogenesis-dependent, because freezing is reduced in animals subject either to $\mathrm{x}$-ray irradiation or to genetic ablation of neurogenesis, whereas cue-dependent fear conditioning and non-stressed spatial learning are unaffected (Saxe et al, 2006). Moreover, the formation of a fear association during training, but not the unconditioned stressor or the expression of fear, has been reported to significantly reduce proliferation of neurogenic cells of the dentate gyrus (Pham et al, 2005). 
Apart from those memory functions that have been specifically linked to new granule cells, it is plausible that the continual alteration of hippocampal circuitry throughout adulthood has gradual long-term effects on interactions with those other brain regions intricately connected with the hippocampus. The limbic-hypothalamic-pituitary-adrenal axis encompasses inputs from the amygdala and prefrontal cortex to the hippocampus, which, via the subiculum, inhibits the paraventricular nucleus (PVN) of the hypothalamus. In addition to this direct pathway between the hippocampus and PVN, an indirect pathway involves excitatory input from the hippocampus to the bed nucleus of the stria terminalis, which provides inhibition to the PVN. The parvocellular neurons of the PVN secrete corticotropin-releasing factor (CRF) onto the anterior lobe of the pituitary gland via the median eminence and portal vessels, resulting in the release of adrenocorticotropic hormone into the general circulation and ultimately stimulating the production of glucocorticoids by the adrenal cortex. Under acute stress conditions, activity of this circuit and the resulting production of glucocorticoids increase dramatically. Negative feedback regulation occurs via glucocorticoid receptors (GRs) and mineralocorticoid receptors (MRs) at several components of the system, including direct inhibition of CRF-secreting cells as well as on hippocampal neurons (reviewed in Lopez et al, 1999).

High glucocorticoid concentrations have been reported to negatively influence the proliferation rate of hippocampal NPCs; this rate is increased by adrenalectomy and decreased by acute corticosterone administration (Cameron and Gould, 1994). However, NPCs do not themselves express either GRs or MRs (Cameron et al, 1993a), indicating that this effect must be mediated by an indirect pathway. This pathway most likely involves NMDA receptor-mediated excitatory signaling of the perforant path from the entorhinal cortex via the subiculum. NPC proliferation can be increased by lesion of the perforant pathway or by administration of NMDA receptor antagonists, which block the effect of corticosterone, and proliferation can be decreased by the administration of NMDA itself (Cameron et al, 1995). Interestingly, NMDA blockade also increases rates of cell death of both mature and newborn granule cells (Gould et al, 1994). Corticosterone concentrations exhibit a U-shaped dose-response relationship with rates of granule cell death: complete removal of corticosterone via adrenalectomy results in cell loss, as do elevated concentrations commensurate with acute stress, meaning that low basal concentrations are optimal for survival. However, this relationship is complicated by the observation that the neurogenic effects of fluoxetine (discussed below in 'Antidepressants and neurogenesis') require the occurrence of diurnal corticosterone rhythms (Huang and Herbert, 2006). It is also notable that the age-related decreases in rates of both hippocampal cell proliferation and spontaneous neuronal death parallel the age-related increase in glucocorticoid secretion (Heine et al, 2004); however, a causal relationship has not been defined.

$5-\mathrm{HT}$ and the $5-\mathrm{HT}_{1 \mathrm{~A}}$ receptor in particular also play a seminal role in hippocampal responses to stress. $5-\mathrm{HT}_{1 \mathrm{~A}}$ receptors are highly colocalized with GR and MR on GABAergic interneurons, which receive serotonergic innervations from the median and dorsal raphe (Patel and
Zhou, 2005). 5-HT release increases sharply in the presence of acute stress, therefore inhibiting the inhibitory influence of the hippocampus onto the PVN (Keeney et al, 2006). Hippocampal 5- $\mathrm{HT}_{1 \mathrm{~A}}$ receptor expression and binding density are decreased by chronic stress; this decrease can be attenuated or blocked by antidepressant administration and appears to be mediated by glucocorticoids (Lopez et al, 1998). Simple increases or decreases in 5-HT transmission do not appear to directly affect NPC proliferation because neither acute 5-HT spikes nor depletion affect proliferation rate (Jha et al, 2006). In contrast, a $5-\mathrm{HT}_{2 \mathrm{~A}}$ receptor antagonist reduces proliferation acutely and increases it when given chronically, and chronic administration of a $5-\mathrm{HT}_{1 \mathrm{~A}}$ receptor agonist increases proliferation (Santarelli et al, 2003; Jha et al, 2008). The NPC proliferation rates of $5-\mathrm{HT}_{1 \mathrm{~A}}$ knockout mice are identical to wild-type mice at baseline and with imipramine-induced increase, but do not exhibit an increase in response to fluoxetine treatment (Santarelli et al, 2003).

\section{ROLE OF NEUROTROPHIC FACTORS}

Neurotrophic factors, particularly brain-derived neurotrophic factor (BDNF), have been shown to play a role in the regulation of neurogenesis in the hippocampus. Neurotrophins are believed to largely affect cell survival via inhibition of apoptotic pathways (Manji et al, 2000). Direct infusion of BDNF into the hippocampus dramatically increases the number of newborn neurons, even contralateral to the injection site, which suggests that this effect does not result exclusively from a direct action upon NPCs or immature neurons (Scharfman et al, 2005). Similarly to central injection, chronic peripheral administration of BDNF has been found to increase survival of newborn cells of the dentate gyrus, via an unknown but necessarily indirect mechanism (Schmidt and Duman, 2010). In slice cultures, BDNF application enhances excitatory synaptic activity of CA1 pyramidal cells, offering a possible indirect pathway and tying BDNF-TrkB signaling to hippocampal learning and memory processes (Tyler and Pozzo-Miller, 2001). However, evidence supporting a direct pathway has also been reported, in that both NPCs and immature neurons do express TrkB, and conditional deletion of the TrkB gene in these cells negatively affects their proliferation, survival, axonal and dendritic growth, and ability to develop LTP, as well as abolishing the effects of imipramine and fluoxetine on proliferation and survival (Sairanen et al, 2005; Bergami et al, 2008; Li et al, 2008). BDNF heterozygote mice show decreased rates of granule cell proliferation and survival, as well as loss of the upregulation of neurogenesis by exposure to an enhanced environment (Sairanen et al, 2005; Rossi et al, 2006). In human populations, healthy subjects carrying the met allele of the val66met BDNF gene polymorphism have been found to have smaller hippocampal and parahippocampal volumes than those with the more common val/val genotype, providing further support for BDNF's importance in maintaining normal cell populations (Bueller et al, 2006; Montag et al, 2009).

In addition to its role in the regulation of neurogenesis, BDNF has been found to have its own antidepressant-like effects. Direct bilateral infusion of BDNF into the dentate 
gyrus decreases the expression of learned helplessness and decreases immobility in the forced swim test (Shirayama et al, 2002). Chronic peripheral administration likewise has anxiolytic and antidepressant effects (Schmidt and Duman, 2010). Transgenic mice overexpressing BDNF in the forebrain (including the cortex and amygdala as well as the hippocampus) show improved performance in the forced swim and protection against CA3 dendritic atrophy induced by chronic stress, but also exhibit increased anxious behavior in an open field and increased amygdalar spine density (Govindarajan et al, 2006). In addition, depressive-like behavior and resistance to the behavioral effects of desipramine and citalopram result from localized knockdown of BDNF in the dentate gyrus, but not of knockdown in CA1 or CA3 (Adachi et al, 2008; Taliaz et al, 2010).

Evidence that hippocampal BDNF may be involved in the regulation of neurogenesis includes the observation that BDNF expression is similarly responsive to chronic stress and antidepressant treatments. In rats, restraint stress, either acute or chronic, decreases BDNF mRNA expression in the dentate gyrus and CA3 of the hippocampus, an effect that can be mimicked with corticosterone administration. However, corticosterone is not essential for this decrease; it is still observed in adrenalectomized animals with or without glucocorticoid replacement (Smith et al, 1995a, b). Chronic unpredictable stress and forced swim have also been seen to significantly decrease hippocampal BDNF expression (Shi et al, 2010; First et al, 2011); however, some experimenters report paradoxical increases in BDNF expression soon after exposures to acute stress (Larsen et al, 2010; Shi et al, 2010). Increased expression of hippocampal (particularly dentate gyrus) BDNF occurs in response to electroconvulsive shock or chronic treatment with any of several classes of antidepressant drugs (Nibuya et al, 1995; Altar et al, 2003; Czubak et al, 2009; Musazzi et al, 2009; Gersner et al, 2010), but also has been seen to timedependently decrease after antidepressant treatment (Alboni et al, 2010). In summary, although the literature regarding BDNF's relationship with neurogenesis largely shows positive interactions, a consensus is not entirely clear.

There is also evidence that vascular endothelial growth factor (VEGF) regulates neurogenesis. VEGF's receptor (Flk-1) is expressed on adult hippocampal NPCs (Yang et al, 2003). Central VEGF infusion increases cell proliferation and increases the number of immature (DCX-expressing) neurons in the SGZ (Jin et al, 2002; Warner-Schmidt and Duman, 2007). Likewise, VEGF knockout mice show decreases in both cell proliferation and numbers of immature neurons (Sun et al, 2006), and viral-mediated VEGF overexpression increases proliferation and survival of new neurons, as well as improving performance in a Morris water maze and a passive avoidance learning task (Cao et al, 2004). As is the case with BDNF, this evidence links VEGF to neurogenesis-associated memory enhancement without ruling out additional effects of non-neurogenic processes such as increased microvasculature and blood flow.

\section{STRESS AND NEUROGENESIS}

Psychological stress has been reported to impair many aspects of hippocampal neurogenesis: decreasing proliferation rate of NPCs, decreasing survival of neuroblasts and immature neurons, and decreasing growth and development of new neurons. Although ischemic and oxidative stressors have also been found to negatively influence neurogenesis, they will not be discussed here. The stress experiments reviewed in this section are summarized in Table 1.

Restraint or immobilization is a classic stressor that has been repeatedly demonstrated to inhibit proliferation, in some reports after only a single session and in others requiring repeated treatment, and also to reduce survival rate of new cells (Pham et al, 2003; Vollmayr et al, 2003; Duric and McCarson, 2006; Koo and Duman, 2008). Reduced hippocampal volume was produced in one experiment utilizing a chronic paradigm of prolonged $(6 \mathrm{~h}$ daily) restraint (Lee et al, 2009). Chronic unpredictable stress or chronic mild stress paradigms, often considered to be a more valid model of human major depression, have also been used to produce deficits in both proliferation and survival, although those including only mild stressors have produced somewhat less consistent results (Heine et al, 2005; Jayatissa et al, 2006; Lee et al, 2006; Xu et al, 2007; Silva et al, 2008; Jayatissa et al, 2010). A more naturally relevant stressor, exposure to the odor of a natural predator, has been reported to reduce proliferation with only a single exposure (Tanapat et al, 2001).

Experiments involving social stress take advantage of male rats' propensity toward establishing dominance hierarchies within a colony to examine social subordination as a chronic low-intensity stress condition. The most elaborate social stress studies involve extensive burrow systems in which animals can be monitored for home environment behavior, such that the effects of inhabiting various levels of a stable hierarchy can be compared between individual animals. In an experiment involving groups of four cohabitating rats, the dominant animal showed significantly higher numbers of surviving immature neurons than the subordinates, although the rate of NPC proliferation was unchanged (Kozorovitskiy and Gould, 2004). A long-standing model using a colony of tree shrews, which form intense and long-lasting dominance hierarchies that are particularly stressful for the subordinate, shows dramatically decreased proliferation, dramatically increased adrenal weights, and decreased hippocampal volume (Lucassen et al, 2001; Simon et al, 2005). The social defeat model (also called the resident-intruder model) restricts psychosocial stress into discrete episodes of conflict: the experimental animal (called the intruder) is only exposed to a larger dominant animal in its home territory (the resident) for short sessions, which can be performed on acute or chronic timelines (Heinrichs et al, 1992; Pulliam et al, 2009). In some variations, the intruder is left in visual and olfactory contact with the resident (eg, separated by a mesh barrier) for a period extending beyond the physical interaction. Reports of the effects of social defeat stress on neurogenesis vary: some studies have demonstrated significant negative effects on cell proliferation and/or neuronal survival, while others have not found such effects (Czeh et al, 2002; Thomas et al, 2007). In addition, social isolation has been reported to intensify deleterious effects of other stressors (Stranahan et al, 2006).

Studies involving variations of electric foot or tail shock have attempted to tease apart the importance of 
Table I Effects of Exposure to Stressors

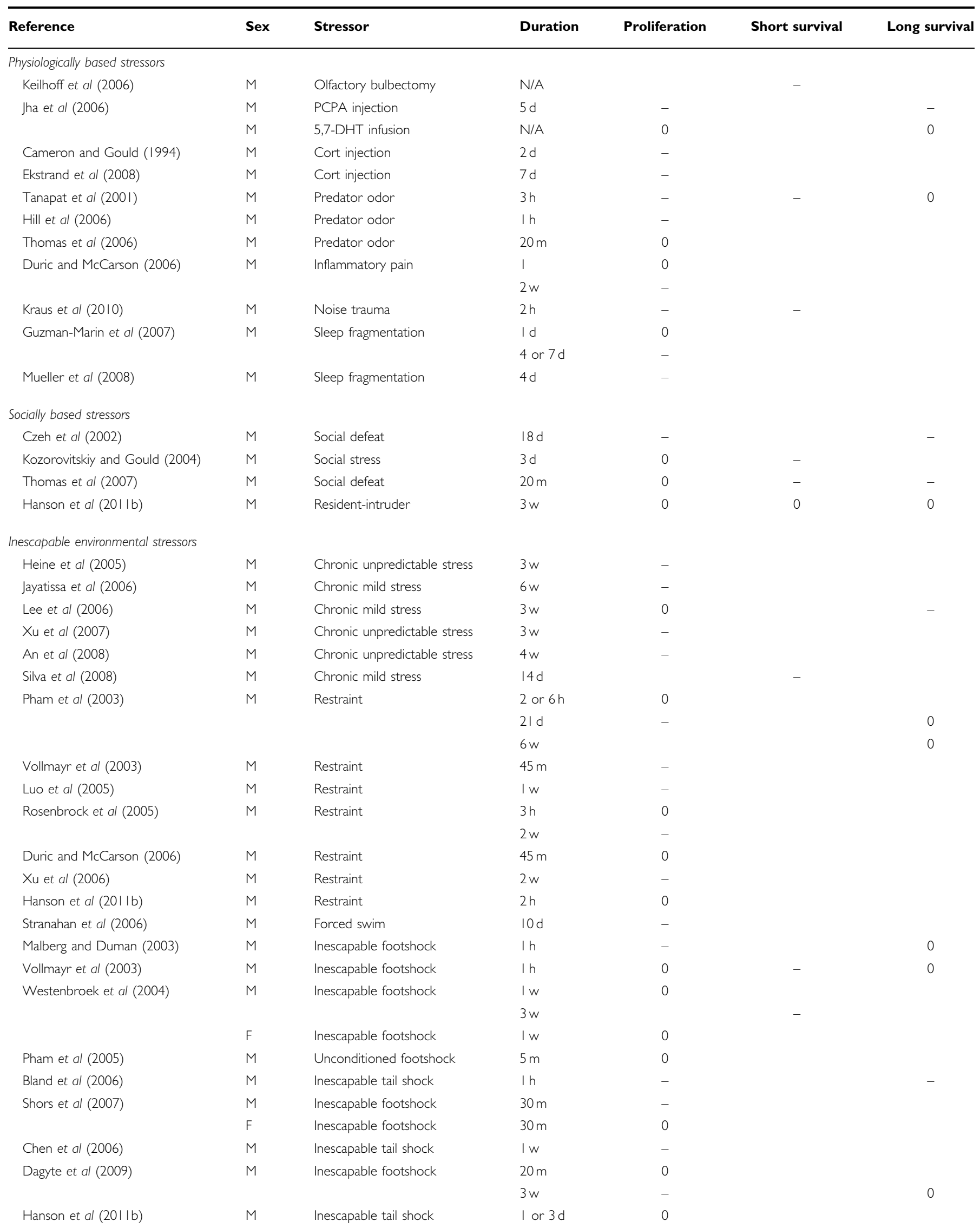


Table I Continued

\begin{tabular}{|c|c|c|c|c|c|c|}
\hline Reference & Sex & Stressor & Duration & Proliferation & Short survival & Long survival \\
\hline \multicolumn{7}{|l|}{ Learning-associated stressors } \\
\hline Malberg and Duman (2003) & M & Escapable footshock & $\mathrm{Ih}$ & 0 & & \\
\hline \multirow[t]{2}{*}{ Van der Borght et al (2005) } & M & Active shock avoidance & Id & 0 & 0 & \\
\hline & & & $4 d$ & 0 & 0 & \\
\hline Shors et al (2007) & $\mathrm{F}$ & Escapable footshock & $30 m$ & 0 & & \\
\hline \multirow[t]{2}{*}{ Mohapel et al (2006) } & M & Water maze & $4 d$ & 0 & 0 & \\
\hline & & & $2 w$ & - & - & \\
\hline Aztiria et al (2007) & M & Water maze & $7 d$ & & - & \\
\hline
\end{tabular}

Abbreviations: PCPA, para-chlorophenylalanine; 5,7-DHT, 5,7-dihydroxytryptamine; N/A, not applicable.

All listed results regard adult rats. Short survival =7-14 days; long survival $=21-28$ days. 0 , no effect, - , decrease, + , increase.

stress-related factors such as fear conditioning and behavioral control. A single session of footshock, either inescapable or as part of avoidance conditioning, has been in some cases enough to reduce NPC proliferation by $50 \%$, regardless of whether animals develop learned helplessness behavior (Malberg and Duman, 2003; Vollmayr et al, 2003). This suggests that any stressor can inhibit neurogenesis when administered at sufficient intensity and duration. However, a report involving tail shock found that a single session reduced proliferation only in those rats developing learned helplessness (Chen et al, 2006). Studies of yoked pairs, in which one animal controls the duration of shock for both partners, have observed all the possible potential outcomes, namely, that both escapable and inescapable conditions result in decreased proliferation, that only the inescapable condition does so, or that neither has any effect on proliferation (Westenbroek et al, 2004; Bland et al, 2006; Shors et al, 2007). Further complicating the story is the fact that virtually all experiments in this area are performed on male animals only; when females are included they often show very different results, such as increased proliferation when males demonstrate a decrease, or no effect when males show a large one (Westenbroek et al, 2004; Shors et al, 2007).

As noted above, a particularly interesting series of experiments revealed that proliferation was only decreased by inescapable shock when the protocol timeline allowed contextual fear associations to occur, suggesting strongly that the important factor is not stress or fear itself, but the emotionally charged learning that takes place under stressful conditions (Pham et al, 2005). However, another study using a similar active avoidance protocol that should allow for contextual conditioning found no change in proliferation or survival rates, even when substantial learning had occurred (Van der Borght et al, 2005). In addition, several reports indicate that proliferation is decreased in animals exposed to stressful conditions, regardless of whether these animals develop depressive-like behaviors, such as learned helplessness or reduced sucrose consumption (Malberg and Duman, 2003; Vollmayr et al, 2003; Jayatissa et al, 2009, 2010), which imply that behavioral adaptations are not necessarily related to alterations in neurogenesis.
Stressful experiences in prenatal and early life, which have lasting effects on behavioral stress response into adulthood, have similarly lasting effects on both basal neurogenesis and its response to stress. Maternally separated rats show decreased NPC proliferation and immature neuron survival, but do not show normal stress-related suppression of these processes (Mirescu et al, 2004). Likewise, adult offspring of dams subjected to restraint stress during gestation show suppressed proliferation and survival, which can be rescued to normal levels by daily handling during the early postnatal period (Lemaire et al, 2006).

Taken as a whole, the literature on effects of stress on the processes of neurogenesis is somewhat discordant. A generally negative impact on NPC proliferation and survival is apparent, with a trend toward more intense and prolonged stressors producing more reliable and robust downregulation. The existence of numerous reports of validated, profound stress procedures, which produce no alterations in neurogenesis, however, prevent complete acceptance of this model. Clearly, stress is a factor in the regulation of neurogenesis, but other factors such as novelty, fear, learning, and spatial representation, which color these stressful experiences significantly modify the impact of the stress itself.

\section{ANTIDEPRESSANTS AND NEUROGENESIS}

A number of antidepressant drugs have been shown to positively influence various aspects of neurogenesis (summarized in Table 2). NPC proliferation rate and immature neuron survival rate have been upregulated by 14 or more days of treatment with the selective 5-HT reuptake inhibitor (SSRI) fluoxetine, but not by shorter treatment regimens (Malberg et al, 2000; Kodama et al, 2004; Huang and Herbert, 2006; Marcussen et al, 2008), although this effect has not been universally observed (Cowen et al, 2008; David et al, 2009; Hanson et al, 2011a). Similar results have been seen in experiments involving the SSRIs citalopram or escitalopram (Jaako-Movits et al, 2006; Jayatissa et al, 2006; Mnie-Filali et al, 2007; Bjornebekk et al, 2010). The tricyclic antidepressant imipramine, although less frequently used in studies of neurogenesis, has been shown to positively 
impact both proliferation and survival (Keilhoff et al, 2006; Surget et al, 2008). In addition, other classes of drugs that are not clinically approved but have shown antidepressant properties in laboratory animals, such as $\mathrm{CRF}_{1}$ antagonists and $\mathrm{V}_{1 \mathrm{~B}}$ antagonists, have shown a similar ability to rescue proliferation rate from a stress-induced deficit, although not to increase it under non-stressed conditions (Alonso et al, 2004; Surget et al, 2008). The mood stabilizers lithium and valproate have been shown to markedly enhance both proliferation and survival (Chen et al, 2000; Hao et al, 2004;

Table 2 Effects of Antidepressant Treatments Under Non-stressed Conditions

\begin{tabular}{|c|c|c|c|c|c|c|}
\hline Reference & Sex & Treatment and dose (mg/kg per day) & Duration & Proliferation & Short survival & Long survival \\
\hline \multicolumn{7}{|l|}{ Electroconvulsive shock } \\
\hline Madsen et al (2000) & M & Electroconvulsive shock & Id & $0 /+$ & & \\
\hline \multirow[t]{2}{*}{ Hellsten et al (2002) } & M & Electroconvulsive shock & Id & & & 0 \\
\hline & & & $5 d$ & & & + \\
\hline \multicolumn{7}{|l|}{ SSR/S } \\
\hline \multirow[t]{2}{*}{ Malberg et al (2000) } & M & Fluoxetine (5) & I or $5 d$ & 0 & & \\
\hline & & & 2 or $4 w$ & + & & + \\
\hline \multirow[t]{2}{*}{ Kodama et al (2004) } & M & Fluoxetine (5) & I w & 0 & & \\
\hline & & & $3 w$ & + & & + \\
\hline Huang and Herbert (2006) & M & Fluoxetine (7) & $2 w$ & + & + & \\
\hline Cowen et al (2008) & M & Fluoxetine (5) & $25 d$ & 0 & & 0 \\
\hline \multirow[t]{2}{*}{ Marcussen et al (2008) } & M & Fluoxetine (10) & $5 d$ & 0 & & \\
\hline & & & $4 w$ & + & & + \\
\hline \multirow[t]{2}{*}{ Pinnock et al (2009) } & M & Fluoxetine (2.5 or 5 ) & $2 w$ & 0 & & \\
\hline & M & Fluoxetine (10) & $2 w$ & + & & \\
\hline Su et al (2009) & M & Fluoxetine (5) & $3 w$ & 0 & & 0 \\
\hline \multirow[t]{2}{*}{ Sui et al (2009) } & M & Fluoxetine (5) & $2 w$ & + & & \\
\hline & & & $4 w$ & + & & + \\
\hline Castro et al (2010) & M & Fluoxetine (10) & $5 w$ & + & + & \\
\hline Bjornebekk et al (20|0) & $\mathrm{F}$ & Escitalopram (25) & $45 d$ & & & + \\
\hline Mostany et al (2008) & M & Venlafaxine (40) & $2 w$ & + & & \\
\hline \multicolumn{7}{|l|}{ Other monoaminergics } \\
\hline Malberg et al (2000) & M & Tranylcypromine (10) & $14 d$ & + & & \\
\hline Keilhoff et al (2006) & M & Imipramine (5) & $15 d$ & & + & \\
\hline \multicolumn{7}{|l|}{ Other treatments } \\
\hline \multirow[t]{2}{*}{ Bai et al (2003) } & M & LY45 I 616 (0.025-0.125) & Id & 0 & & \\
\hline & & & $3 w$ & + & & \\
\hline Banasr et al (2006) & M & Agomelatine (40) & $1,3,6 \mathrm{w}$ & 0 & & + \\
\hline Hanson et al (20।la) & M & $\mathrm{R} \mid 21919(30)$ & $3 w$ & 0 & & \\
\hline Czeh et al (2002) & M & Transcranial magnetic stimulation & $18 d$ & 0 & & 0 \\
\hline Grassi Zucconi et al (2006) & M & Sleep deprivation & Id & + & + & + \\
\hline
\end{tabular}

All listed results regard adult rats. Short survival $=7-14$ days; long survival $=21-28$ days. 0 , no effect; - , decrease; + , increase. 
Silva et al, 2008; Hanson et al, 2011a). It is not known whether issues of dosing equivalency between various labs and individual experiments are responsible for the observed differences across drugs within the same class.

Non-drug treatments that have behavioral antidepressant effects also positively affect neurogenesis. A single electroconvulsive seizure (ECS), purportedly analogous to the electroconvulsant therapy used clinically to treat major depression, causes a profound increase in the number of new neurons surviving up to 2 months afterward. With multiple sessions, NPC proliferation rate also shows a dramatic increase, greater than that observed with fluoxetine (Madsen et al, 2000; Malberg et al, 2000). ECS has even been able to restore some degree of neurogenesis after disruption by $\mathrm{x}$-ray irradiation, as well as restoring the corresponding deficits in contextual fear conditioning (Warner-Schmidt et al, 2008). A home-cage environment enriched to encourage exploratory behavior, as discussed above in 'Importance of neurogenesis in hippocampal function', promotes neurogenesis in a spatial learning context. Enriched environment can also relieve stressinduced depressive and anxious behaviors, a benefit that has been seen to involve or even require neurogenesis (Kronenberg et al, 2003; Veena et al, 2009; Schloesser et al, 2010). Exercise, either forced or voluntary, likewise has been shown to both increase NPC proliferation and decrease depressive and anxious behaviors (Olson et al, 2006; Yi et al, 2009; Brandt et al, 2010).

As is the case with stress-induced downregulation of neurogenesis, antidepressant-induced upregulation of neurogenesis forms a trend, rather than a reliable association. Numerous demonstrations have been made of varying types of antidepressant treatments notably increasing NPC proliferation and survival, but a substantial number of negative findings have been reported as well, particularly in the context of multi-drug experiments where some but not all treatments show significant effects.

\section{THE NEUROGENESIS HYPOTHESIS OF DEPRESSION}

Based on evidence described that hippocampal neurogenesis is (1) downregulated under stressful conditions, including those that result in laboratory animal models of depressive-like behaviors, and (2) upregulated by antidepressant drugs and other antidepressant treatments, the hypothesis emerged that neurogenesis and other related aspects of hippocampal plasticity are integrally involved in the pathophysiology of major depressive disorder (MDD) and its effective treatment. Some experiments have even suggested that neurogenesis is necessary for the behavioral effects of antidepressants, particularly hedonic or noveltyassociated effects (Santarelli et al, 2003; David et al, 2009). Clinical evidence supporting this hypothesis includes reports of reduced hippocampal volume in MRI or post-mortem studies of MDD patients. Meta-analysis of 32 publications found that volume is significantly reduced with greater than one lifetime major depressive episode or greater than 2 years of illness, suggesting that the observed atrophy is resultant from the burden of illness rather than being a pre-existing risk factor (McKinnon et al, 2009). Evidence has even been found for increased proliferation of NPCs in antidepressant-treated vs -untreated MDD (Boldrini et al, 2009). However, discrepant reports have appeared, and there is evidence that reduced hippocampal volume may be associated with a history of child abuse and neglect or confounded by comorbid post-traumatic stress disorder in depressed women (Stein et al, 1997; Gilbertson et al, 2002; Vythilingam et al, 2002).

Nevertheless, the hypothesis has been recently subjected to serious criticisms. Many factors other than decreased neuron number could account for hippocampal volume changes: tissue from MDD patients has been found to have increased granule cell and pyramidal cell density, presumably from decreased neurophil, and the possibility of altered fluid content also exists (Stockmeier et al, 2004). The effects of chronic stress or experimentally elevated corticosterone concentrations on dendritic atrophy and loss of synapses have been well documented in laboratory animals (Sousa et al, 2000; Vyas et al, 2002; Tata and Anderson, 2010). This atrophy can be reversed by the administration of antidepressants of multiple classes, and in fact, the behavioral effects of chronic stress and antidepressants in the sucrose consumption test and forced swim test have been found to be associated more closely with the complexity of the dendritic arbor of granule and pyramidal cells than with neurogenesis (Bessa et al, 2009). In addition, fluoxetine and paroxetine have been seen to induce mature granule cells to revert to an immature phenotype, wherein expression of c-fos and calretinin are decreased and calbindin increased to early postmitotic levels. Such changes in the expression of maturation-associated proteins might result in experimental mistaking of these granule cells for truly newborn ones. Synaptic plasticity in SSRI-treated granule cells is also altered to resemble patterns seen in immature neurons, including enhanced LTD and suppressed LTP (Kobayashi et al, 2010). This 'dematuration' of older granule cells to more plastic functional states may allow many of the putative cognitive processing functions of newborn neurons to be performed without requiring a high volume of new cell generation as has been proposed previously (Deisseroth et al, 2004; Wiskott et al, 2006).

Another counterargument to the hypothesis is the finding that experimental disruption of neurogenesis does not produce depression-like behavior, nor does it render animals more sensitive to the behavioral effects of chronic stress (Surget et al, 2008; Jayatissa et al, 2009). In addition, there are now reports of antidepressants at behaviorally active or clinically relevant doses that exert no effect upon NPC proliferation or immature neuron number (see Table 2). Another complication arises when comparing studies using $\mathrm{x}$-ray irradiation to block neurogenesis and those using the chemical agent methylazoxymethanol (MAM): while both methods interrupt cell proliferation in targeted areas, MAM does not block the effects of antidepressant drugs (cf. Surget et al, 2008; Bessa et al, 2009). Thus, it seems likely that some of the effects of hippocampal $x$-ray irradiation are due less to deficits in neurogenesis than to other alterations caused by the radiation.

To summarize, initial evidence regarding the effects of psychological stress and antidepressant drugs on adult neurogenesis in laboratory animals led to the development of the neurogenesis hypothesis of depression, which has 
supportive evidence in many experimental settings. However, the emergence of contradictory reports and failed replications requires a revision of this hypothesis to state that neurogenesis in the adult dentate gyrus can be regulated by stress and antidepressants under certain as-yet-undefined conditions, but that this regulation is not an intrinsic property of all psychological stress, depression, and antidepressant treatments. It seems most likely that neurogenesis is only one, more visible aspect of a complex array of neuroplastic functions that occur in the adult hippocampus, and that the various factors involved in this neuroplastic environment are responsive to external influences, which often accompany but are not inherently linked with the pathophysiology and pharmacological treatment of depression and depression-like behaviors.

\section{ACKNOWLEDGEMENTS}

We thank Amanda Hoppers for her assistance in figure preparation.

\section{DISCLOSURE}

Financial disclosure (preceding 12 months or anticipated in next 12 months):

Nicola D Hanson, PhD

Current employment: TRM Oncology.

Michael J Owens, PhD

Research Grants: NIH, Eli Lilly, Lundbeck A/S, Cyberonics, Ortho-McNeil Janssen, AstraZeneca, Dainippon Sumitomo Pharma, SK Life Sciences, Sunovion Pharmaceuticals. Consultant: H Lundbeck A/S, RJ Reynolds.

Patent: Method of assessing antidepressant drug therapy via transport inhibition of monoamine neurotransmitters (US 7148027 B2).

Charles B Nemeroff, MD, PhD

Research/Grants: National Institutes of Health (NIH), Agency for Healthcare Research and Quality (AHRQ).

Speakers Bureau: None.

Consulting: Xhale, Takeda.

Stockholder: CeNeRx BioPharma, NovaDel Pharma, PharmaNeuroBoost, Revaax Pharma, Xhale.

Other Financial Interests: CeNeRx BioPharma, PharmaNeuroBoost.

Patents: Method and devices for transdermal delivery of lithium (US 6375 990B1), Method of assessing antidepressant drug therapy via transport inhibition of monoamine neurotransmitters by ex vivo assay (US 7148 027B2).

Scientific Advisory Boards: American Foundation for Suicide Prevention (AFSP), CeNeRx BioPharma, National Alliance for Research on Schizophrenia and Depression (NARSAD), NovaDel Pharma, PharmaNeuroBoost, Anxiety

Disorders Association of America (ADAA).

Board of Directors: AFSP, NovaDel Pharma.

\section{REFERENCES}

Adachi M, Barrot M, Autry AE, Theobald D, Monteggia LM (2008). Selective loss of brain-derived neurotrophic factor in the dentate gyrus attenuates antidepressant efficacy. Biol Psychiatry 63: 642-649.
Alboni S, Benatti C, Capone G, Corsini D, Caggia F, Tascedda F et al (2010). Time-dependent effects of escitalopram on brain derived neurotrophic factor (bdnf) and neuroplasticity related targets in the central nervous system of rats. Eur J Pharmacol 643: $180-187$.

Alonso R, Griebel G, Pavone G, Stemmelin J, Le Fur G, Soubrie P (2004). Blockade of $\operatorname{crf}(1)$ or $\mathrm{v}(1 \mathrm{~b})$ receptors reverses stressinduced suppression of neurogenesis in a mouse model of depression. Mol Psychiatry 9: 278-286, 224.

Altar CA, Whitehead RE, Chen R, Wortwein G, Madsen TM (2003). Effects of electroconvulsive seizures and antidepressant drugs on brain-derived neurotrophic factor protein in rat brain. Biol Psychiatry 54: 703-709.

Altman J, Das GD (1965). Autoradiographic and histological evidence of postnatal hippocampal neurogenesis in rats. J Comp Neurol 124: 319-335.

An L, Zhang YZ, Yu NJ, Liu XM, Zhao N, Yuan L et al (2008). The total flavonoids extracted from xiaobuxin-tang up-regulate the decreased hippocampal neurogenesis and neurotrophic molecules expression in chronically stressed rats. Prog Neuropsychopharmacol Biol Psychiatry 32: 1484-1490.

Aztiria E, Capodieci G, Arancio L, Leanza G (2007). Extensive training in a maze task reduces neurogenesis in the adult rat dentate gyrus probably as a result of stress. Neurosci Lett 416: 133-137.

Bai F, Bergeron M, Nelson DL (2003). Chronic ampa receptor potentiator (ly451646) treatment increases cell proliferation in adult rat hippocampus. Neuropharmacology 44: 1013-1021.

Banasr M, Soumier A, Hery M, Mocaer E, Daszuta A (2006). Agomelatine, a new antidepressant, induces regional changes in hippocampal neurogenesis. Biol Psychiatry 59: 1087-1096.

Bergami M, Rimondini R, Santi S, Blum R, Gotz M, Canossa M (2008). Deletion of trkb in adult progenitors alters newborn neuron integration into hippocampal circuits and increases anxiety-like behavior. Proc Natl Acad Sci USA 105: 15570-15575.

Bessa JM, Ferreira D, Melo I, Marques F, Cerqueira JJ, Palha JA et al (2009). The mood-improving actions of antidepressants do not depend on neurogenesis but are associated with neuronal remodeling. Mol Psychiatry 14: 764-773, 739.

Bhardwaj RD, Curtis MA, Spalding KL, Buchholz BA, Fink D, Bjork-Eriksson $\mathrm{T}$ et al (2006). Neocortical neurogenesis in humans is restricted to development. Proc Natl Acad Sci USA 103: 12564-12568.

Bjornebekk A, Mathe AA, Brene S (2010). The antidepressant effects of running and escitalopram are associated with levels of hippocampal npy and y1 receptor but not cell proliferation in a rat model of depression. Hippocampus 20: 820-828.

Bland ST, Schmid MJ, Greenwood BN, Watkins LR, Maier SF (2006). Behavioral control of the stressor modulates stressinduced changes in neurogenesis and fibroblast growth factor-2. NeuroReport 17: 593-597.

Boldrini M, Underwood MD, Hen R, Rosoklija GB, Dwork AJ, John Mann J et al (2009). Antidepressants increase neural progenitor cells in the human hippocampus. Neuropsychopharmacology 34: 2376-2389.

Bonaguidi MA, Wheeler MA, Shapiro JS, Stadel RP, Sun GJ, Ming GL et al (2011). In vivo clonal analysis reveals selfrenewing and multipotent adult neural stem cell characteristics. Cell 145: 1142-1155.

Brandt MD, Maass A, Kempermann G, Storch A (2010). Physical exercise increases notch activity, proliferation and cell cycle exit of type-3 progenitor cells in adult hippocampal neurogenesis. Eur J Neurosci 32: 1256-1264.

Bueller JA, Aftab M, Sen S, Gomez-Hassan D, Burmeister M, Zubieta JK (2006). Bdnf val66met allele is associated with reduced hippocampal volume in healthy subjects. Biol Psychiatry 59: $812-815$. 
Cameron HA, Dayer AG (2008). New interneurons in the adult neocortex: small, sparse, but significant? Biol Psychiatry 63: 650-655.

Cameron HA, Gould E (1994). Adult neurogenesis is regulated by adrenal steroids in the dentate gyrus. Neuroscience 61: 203-209.

Cameron HA, McEwen BS, Gould E (1995). Regulation of adult neurogenesis by excitatory input and nmda receptor activation in the dentate gyrus. J Neurosci 15: 4687-4692.

Cameron HA, McKay RD (2001). Adult neurogenesis produces a large pool of new granule cells in the dentate gyrus. J Comp Neurol 435: 406-417.

Cameron HA, Woolley CS, Gould E (1993a). Adrenal steroid receptor immunoreactivity in cells born in the adult rat dentate gyrus. Brain Res 611: 342-346.

Cameron HA, Woolley CS, McEwen BS, Gould E (1993b). Differentiation of newly born neurons and glia in the dentate gyrus of the adult rat. Neuroscience 56: 337-344.

Cao L, Jiao X, Zuzga DS, Liu Y, Fong DM, Young D et al (2004). Vegf links hippocampal activity with neurogenesis, learning and memory. Nat Genet 36: 827-835.

Castro JE, Varea E, Marquez C, Cordero MI, Poirier G, Sandi C (2010). Role of the amygdala in antidepressant effects on hippocampal cell proliferation and survival and on depressionlike behavior in the rat. PLoS One 5: e8618.

Chen G, Rajkowska G, Du F, Seraji-Bozorgzad N, Manji HK (2000). Enhancement of hippocampal neurogenesis by lithium. J Neurochem 75: 1729-1734.

Chen H, Pandey GN, Dwivedi Y (2006). Hippocampal cell proliferation regulation by repeated stress and antidepressants. NeuroReport 17: 863-867.

Clelland CD, Choi M, Romberg C, Clemenson Jr GD, Fragniere A, Tyers $P$ et al (2009). A functional role for adult hippocampal neurogenesis in spatial pattern separation. Science 325: 210-213.

Cowen DS, Takase LF, Fornal CA, Jacobs BL (2008). Agedependent decline in hippocampal neurogenesis is not altered by chronic treatment with fluoxetine. Brain Res 1228: 14-19.

Czeh B, Welt T, Fischer AK, Erhardt A, Schmitt W, Muller MB et al (2002). Chronic psychosocial stress and concomitant repetitive transcranial magnetic stimulation: effects on stress hormone levels and adult hippocampal neurogenesis. Biol Psychiatry 52: 1057-1065.

Czubak A, Nowakowska E, Kus K, Burda K, Metelska J, BaerDubowska W et al (2009). Influences of chronic venlafaxine, olanzapine and nicotine on the hippocampal and cortical concentrations of brain-derived neurotrophic factor (bdnf). Pharmacol Rep 61: 1017-1023.

Dagyte G, Van der Zee EA, Postema F, Luiten PG, Den Boer JA, Trentani A et al (2009). Chronic but not acute foot-shock stress leads to temporary suppression of cell proliferation in rat hippocampus. Neuroscience 162: 904-913.

David DJ, Samuels BA, Rainer Q, Wang JW, Marsteller D, Mendez I et al (2009). Neurogenesis-dependent and -independent effects of fluoxetine in an animal model of anxiety/depression. Neuron 62: 479-493.

Deisseroth K, Singla S, Toda H, Monje M, Palmer TD, Malenka RC (2004). Excitation-neurogenesis coupling in adult neural stem/ progenitor cells. Neuron 42: 535-552.

Duric V, McCarson KE (2006). Persistent pain produces stress-like alterations in hippocampal neurogenesis and gene expression. J Pain 7: 544-555.

Ekstrand J, Hellsten J, Wennstrom M, Tingstrom A (2008). Differential inhibition of neurogenesis and angiogenesis by corticosterone in rats stimulated with electroconvulsive seizures. Prog Neuropsychopharmacol Biol Psychiatry 32: 1466-1472.

Encinas JM, Vaahtokari A, Enikolopov G (2006). Fluoxetine targets early progenitor cells in the adult brain. Proc Natl Acad Sci USA 103: $8233-8238$.
Epp JR, Galea LA (2009). Hippocampus-dependent strategy choice predicts

low levels of cell proliferation in the dentate gyrus. Neurobiol Learn Mem 91: 437-446.

Eriksson PS, Perfilieva E, Bjork-Eriksson T, Alborn AM, Nordborg C, Peterson DA et al (1998). Neurogenesis in the adult human hippocampus. Nat Med 4: 1313-1317.

First M, Gil-Ad I, Taler M, Tarasenko I, Novak N, Weizman A (2011). The effects of fluoxetine treatment in a chronic mild stress rat model on depression-related behavior, brain neurotrophins and erk expression. J Mol Neurosci (e-pub ahead of print) doi:10.1007/S12031-011-9515.5.

Garcia-Verdugo JM, Doetsch F, Wichterle H, Lim DA, AlvarezBuylla A (1998). Architecture and cell types of the adult subventricular zone: in search of the stem cells. J Neurobiol 36: 234-248.

Ge S, Goh EL, Sailor KA, Kitabatake Y, Ming GL, Song H (2006). Gaba regulates synaptic integration of newly generated neurons in the adult brain. Nature 439: 589-593.

Ge S, Yang CH, Hsu KS, Ming GL, Song H (2007). A critical period for enhanced synaptic plasticity in newly generated neurons of the adult brain. Neuron 54: 559-566.

Gersner R, Toth E, Isserles M, Zangen A (2010). Site-specific antidepressant effects of repeated subconvulsive electrical stimulation: potential role of brain-derived neurotrophic factor. Biol Psychiatry 67: 125-132.

Gilbertson MW, Shenton ME, Ciszewski A, Kasai K, Lasko NB, Orr SP et al (2002). Smaller hippocampal volume predicts pathologic vulnerability to psychological trauma. Nat Neurosci 5: $1242-1247$

Gould E (2007). How wide spread is adult neurogenesis in mammals? Nat Rev Neurosci 8: 481-488.

Gould E, Beylin A, Tanapat P, Reeves A, Shors TJ (1999). Learning enhances adult neurogenesis in the hippocampal formation. Nat Neurosci 2: 260-265.

Gould E, Cameron HA, McEwen BS (1994). Blockade of nmda receptors increases cell death and birth in the developing rat dentate gyrus. J Comp Neurol 340: 551-565.

Govindarajan A, Rao BS, Nair D, Trinh M, Mawjee N, Tonegawa S et al (2006). Transgenic brain-derived neurotrophic factor expression causes both anxiogenic and antidepressant effects. Proc Natl Acad Sci USA 103: 13208-13213.

Grassi Zucconi G, Cipriani S, Balgkouranidou I, Scattoni R (2006). 'One night' sleep deprivation stimulates hippocampal neurogenesis. Brain Res Bull 69: 375-381.

Green W, Patil P, Marsden CA, Bennett GW, Wigmore PM (2006). Treatment with olanzapine increases cell proliferation in the subventricular zone and prefrontal cortex. Brain Res 1070: 242-245.

Guzman-Marin R, Suntsova N, Bashir T, Szymusiak R, McGinty D (2007). Cell proliferation in the dentate gyrus of the adult rat fluctuates with the light-dark cycle. Neurosci Lett 422: 198-201.

Hancock A, Priester C, Kidder E, Keith JR (2009). Does 5-bromo2 -deoxyuridine (brdu) disrupt cell proliferation and neuronal maturation in the adult rat hippocampus in vivo? Behav Brain Res 199: 218-221.

Hanson ND, Nemeroff CB, Owens MJ (2011a). Lithium, but not fluoxetine or the crf1 receptor antagonist r121919, increases cell proliferation in the adult dentate gyrus. J Pharmacol Exp Ther 337: $180-186$.

Hanson ND, Owens MJ, Boss-Williams KA, Weiss JM, Nemeroff CB (2011b). Several stressors fail to reduce adult hippocampal neurogenesis. Psychoneuroendocrinology (e-pub ahead of print 18 May 2011).

Hao Y, Creson T, Zhang L, Li P, Du F, Yuan P et al (2004). Mood stabilizer valproate promotes erk pathway-dependent cortical neuronal growth and neurogenesis. J Neurosci 24: 6590-6599. 
Heine VM, Maslam S, Joels M, Lucassen PJ (2004). Prominent decline of newborn cell proliferation, differentiation, and apoptosis in the aging dentate gyrus, in absence of an age-related hypothalamus-pituitary-adrenal axis activation. Neurobiol Aging 25: 361-375.

Heine VM, Zareno J, Maslam S, Joels M, Lucassen PJ (2005). Chronic stress in the adult dentate gyrus reduces cell proliferation near the vasculature and vegf and flk-1 protein expression. Eur J Neurosci 21: 1304-1314.

Heinrichs SC, Pich EM, Miczek KA, Britton KT, Koob GF (1992). Corticotropin-releasing factor antagonist reduces emotionality in socially defeated rats via direct neurotropic action. Brain Res 581: $190-197$.

Hellsten J, Wennstrom M, Mohapel P, Ekdahl CT, Bengzon J, Tingstrom A (2002). Electroconvulsive seizures increase hippocampal neurogenesis after chronic corticosterone treatment. Eur J Neurosci 16: 283-290.

Hill MN, Kambo JS, Sun JC, Gorzalka BB, Galea LA (2006). Endocannabinoids modulate stress-induced suppression of hippocampal cell proliferation and activation of defensive behaviours. Eur J Neurosci 24: 1845-1849.

Huang GJ, Herbert J (2006). Stimulation of neurogenesis in the hippocampus of the adult rat by fluoxetine requires rhythmic change in corticosterone. Biol Psychiatry 59: 619-624.

Jaako-Movits K, Zharkovsky T, Pedersen M, Zharkovsky A (2006). Decreased hippocampal neurogenesis following olfactory bulbectomy is reversed by repeated citalopram administration. Cell Mol Neurobiol 26: 1559-1570.

Jayatissa MN, Bisgaard C, Tingstrom A, Papp M, Wiborg O (2006). Hippocampal cytogenesis correlates to escitalopram-mediated recovery in a chronic mild stress rat model of depression. Neuropsychopharmacology 31: 2395-2404.

Jayatissa MN, Henningsen K, Nikolajsen G, West MJ, Wiborg O (2010). A reduced number of hippocampal granule cells does not associate with an anhedonia-like phenotype in a rat chronic mild stress model of depression. Stress 13: 95-105.

Jayatissa MN, Henningsen K, West MJ, Wiborg O (2009). Decreased cell proliferation in the dentate gyrus does not associate with development of anhedonic-like symptoms in rats. Brain Res 1290: 133-141.

Jha S, Rajendran R, Davda J, Vaidya VA (2006). Selective serotonin depletion does not regulate hippocampal neurogenesis in the adult rat brain: differential effects of $p$-chlorophenylalanine and 5,7-dihydroxytryptamine. Brain Res 1075: 48-59.

Jha S, Rajendran R, Fernandes KA, Vaidya VA (2008). 5-Ht2a/2c receptor blockade regulates progenitor cell proliferation in the adult rat hippocampus. Neurosci Lett 441: 210-214.

Jin K, Zhu Y, Sun Y, Mao XO, Xie L, Greenberg DA (2002). Vascular endothelial growth factor (vegf) stimulates neurogenesis in vitro and in vivo. Proc Natl Acad Sci USA 99: 11946-11950.

Kaplan MS, Hinds JW (1977). Neurogenesis in the adult rat: electron microscopic analysis of light radioautographs. Science 197: 1092-1094.

Kee N, Sivalingam S, Boonstra R, Wojtowicz JM (2002). The utility of ki-67 and brdu as proliferative markers of adult neurogenesis. J Neurosci Methods 115: 97-105.

Keeney A, Jessop DS, Harbuz MS, Marsden CA, Hogg S, Blackburn-Munro RE (2006). Differential effects of acute and chronic social defeat stress on hypothalamic-pituitary-adrenal axis function and hippocampal serotonin release in mice. J Neuroendocrinol 18: 330-338.

Keilhoff G, Becker A, Grecksch G, Bernstein HG, Wolf G (2006). Cell proliferation is influenced by bulbectomy and normalized by imipramine treatment in a region-specific manner. Neuropsychopharmacology 31: 1165-1176.

Kempermann G, Jessberger S, Steiner B, Kronenberg G (2004). Milestones of neuronal development in the adult hippocampus. Trends Neurosci 27: 447-452.
Kobayashi K, Ikeda Y, Sakai A, Yamasaki N, Haneda E, Miyakawa $\mathrm{T}$ et al (2010). Reversal of hippocampal neuronal maturation by serotonergic antidepressants. Proc Natl Acad Sci USA 107: 8434-8439.

Kodama M, Fujioka T, Duman RS (2004). Chronic olanzapine or fluoxetine administration increases cell proliferation in hippocampus and prefrontal cortex of adult rat. Biol Psychiatry 56: $570-580$.

Koo JW, Duman RS (2008). Il-1beta is an essential mediator of the antineurogenic and anhedonic effects of stress. Proc Natl Acad Sci USA 105: 751-756.

Kozorovitskiy Y, Gould E (2004). Dominance hierarchy influences adult neurogenesis in the dentate gyrus. $J$ Neurosci 24: 6755-6759.

Kraus KS, Mitra S, Jimenez Z, Hinduja S, Ding D, Jiang $\mathrm{H}$ et al (2010). Noise trauma impairs neurogenesis in the rat hippocampus. Neuroscience 167: 1216-1226.

Kronenberg G, Reuter K, Steiner B, Brandt MD, Jessberger S, Yamaguchi $\mathrm{M}$ et al (2003). Subpopulations of proliferating cells of the adult hippocampus respond differently to physiologic neurogenic stimuli. J Comp Neurol 467: 455-463.

Larsen MH, Mikkelsen JD, Hay-Schmidt A, Sandi C (2010). Regulation of brain-derived neurotrophic factor (bdnf) in the chronic unpredictable stress rat model and the effects of chronic antidepressant treatment. J Psychiatr Res 44: 808-816.

Larsen MH, Rosenbrock H, Sams-Dodd F, Mikkelsen JD (2007). Expression of brain derived neurotrophic factor, activityregulated cytoskeleton protein mrna, and enhancement of adult hippocampal neurogenesis in rats after sub-chronic and chronic treatment with the triple monoamine re-uptake inhibitor tesofensine. Eur J Pharmacol 555: 115-121.

Lee AL, Ogle WO, Sapolsky RM (2002). Stress and depression: possible links to neuron death in the hippocampus. Bipolar Disord 4: 117-128.

Lee KJ, Kim SJ, Kim SW, Choi SH, Shin YC, Park SH et al (2006). Chronic mild stress decreases survival, but not proliferation, of new-born cells in adult rat hippocampus. Exp Mol Med 38: 44-54.

Lee T, Jarome T, Li SJ, Kim JJ, Helmstetter FJ (2009). Chronic stress selectively reduces hippocampal volume in rats: a longitudinal magnetic resonance imaging study. NeuroReport 20: 1554-1558.

Lemaire V, Lamarque S, Le Moal M, Piazza PV, Abrous DN (2006). Postnatal stimulation of the pups counteracts prenatal stressinduced deficits in hippocampal neurogenesis. Biol Psychiatry 59: 786-792.

Leuner B, Gould E, Shors TJ (2006). Is there a link between adult neurogenesis and learning? Hippocampus 16: 216-224.

Li Y, Luikart BW, Birnbaum S, Chen J, Kwon CH, Kernie SG et al (2008).

Trkb regulates hippocampal neurogenesis and governs sensitivity to antidepressive treatment. Neuron 59: 399-412.

Lopez JF, Akil H, Watson SJ (1999). Neural circuits mediating stress. Biol Psychiatry 46: 1461-1471.

Lopez JF, Chalmers DT, Little KY, Watson SJ (1998). A.E. Bennett research award. Regulation of serotoninla, glucocorticoid, and mineralocorticoid receptor in rat and human hippocampus: implications for the neurobiology of depression. Biol Psychiatry 43: $547-573$.

Lucassen PJ, Vollmann-Honsdorf GK, Gleisberg M, Czeh B, De Kloet ER, Fuchs E (2001). Chronic psychosocial stress differentially affects apoptosis in hippocampal subregions and cortex of the adult tree shrew. Eur J Neurosci 14: 161-166.

Luo C, Xu H, Li XM (2005). Quetiapine reverses the suppression of hippocampal neurogenesis caused by repeated restraint stress. Brain Res 1063: 32-39.

Madsen TM, Treschow A, Bengzon J, Bolwig TG, Lindvall O, Tingstrom A (2000). Increased neurogenesis in a model of electroconvulsive therapy. Biol Psychiatry 47: 1043-1049. 
Malberg JE, Duman RS (2003). Cell proliferation in adult hippocampus is decreased by inescapable stress: reversal by fluoxetine treatment. Neuropsychopharmacology 28: 1562-1571.

Malberg JE, Eisch AJ, Nestler EJ, Duman RS (2000). Chronic antidepressant treatment increases neurogenesis in adult rat hippocampus. J Neurosci 20: 9104-9110.

Manji HK, Moore GJ, Rajkowska G, Chen G (2000). Neuroplasticity and cellular resilience in mood disorders. Mol Psychiatry 5: 578-593.

Marcussen AB, Flagstad P, Kristjansen PE, Johansen FF, Englund U (2008). Increase in neurogenesis and behavioural benefit after chronic fluoxetine treatment in wistar rats. Acta Neurol Scand 117: $94-100$.

McEwen BS (2001). Plasticity of the hippocampus: adaptation to chronic stress and allostatic load. Ann N Y Acad Sci 933: 265-277.

McKinnon MC, Yucel K, Nazarov A, MacQueen GM (2009). A meta-analysis examining clinical predictors of hippocampal volume in patients with major depressive disorder. J Psychiatry Neurosci 34: 41-54.

Mirescu C, Peters JD, Gould E (2004). Early life experience alters response of adult neurogenesis to stress. Nat Neurosci 7: 841-846.

Mnie-Filali O, Faure C, Mansari ME, Lambas-Senas L, Berod A, Zimmer L et al (2007). R-citalopram prevents the neuronal adaptive changes induced by escitalopram. NeuroReport 18: 1553-1556.

Mohapel P, Mundt-Petersen K, Brundin P, Frielingsdorf H (2006). Working

memory training decreases hippocampal neurogenesis. Neuroscience 142: 609-613.

Montag C, Weber B, Fliessbach K, Elger C, Reuter M (2009). The bdnf val66met polymorphism impacts parahippocampal and amygdala volume in healthy humans: incremental support for a genetic risk factor for depression. Psychol Med 39: 1831-1839.

Mostany R, Valdizan EM, Pazos A (2008). A role for nuclear beta-catenin in snri antidepressant-induced hippocampal cell proliferation. Neuropharmacology 55: 18-26.

Mueller AD, Pollock MS, Lieblich SE, Epp JR, Galea LA, Mistlberger RE (2008). Sleep deprivation can inhibit adult hippocampal neurogenesis independent of adrenal stress hormones. Am J Physiol Regul Integr Comp Physiol 294: R1693-R1703.

Musazzi L, Cattaneo A, Tardito D, Barbon A, Gennarelli M, Barlati $S$ et al (2009). Early raise of bdnf in hippocampus suggests induction of posttranscriptional mechanisms by antidepressants. BMC Neurosci 10: 48.

Nasrallah HA, Hopkins T, Pixley SK (2010). Differential effects of antipsychotic and antidepressant drugs on neurogenic regions in rats. Brain Res 1354: 23-29.

Nibuya M, Morinobu S, Duman RS (1995). Regulation of bdnf and trkb mrna in rat brain by chronic electroconvulsive seizure and antidepressant drug treatments. J Neurosci 15: 7539-7547.

Olson AK, Eadie BD, Ernst C, Christie BR (2006). Environmental enrichment and voluntary exercise massively increase neurogenesis in the adult hippocampus via dissociable pathways. Hippocampus 16: 250-260.

Patel TD, Zhou FC (2005). Ontogeny of 5-htla receptor expression in the developing hippocampus. Brain Res Dev Brain Res 157: 42-57.

Pham K, McEwen BS, Ledoux JE, Nader K (2005). Fear learning transiently impairs hippocampal cell proliferation. Neuroscience 130: $17-24$.

Pham K, Nacher J, Hof PR, McEwen BS (2003). Repeated restraint stress suppresses neurogenesis and induces biphasic psa-ncam expression in the adult rat dentate gyrus. Eur J Neurosci 17: 879-886.

Pinnock SB, Lazic SE, Wong HT, Wong IH, Herbert J (2009). Synergistic effects of dehydroepiandrosterone and fluoxetine on proliferation of progenitor cells in the dentate gyrus of the adult male rat. Neuroscience 158: 1644-1651.

Pulliam JV, Dawaghreh AM, Alema-Mensah E, Plotsky PM (2009). Social defeat stress produces prolonged alterations in acoustic startle and body weight gain in male long Evans rats. J Psychiatr Res 44: 106-111.

Raber J, Rola R, LeFevour A, Morhardt D, Curley J, Mizumatsu S et al (2004). Radiation-induced cognitive impairments are associated with changes in indicators of hippocampal neurogenesis. Radiat Res 162: 39-47.

Rosenbrock H, Koros E, Bloching A, Podhorna J, Borsini F (2005). Effect of chronic intermittent restraint stress on hippocampal expression of marker proteins for synaptic plasticity and progenitor cell proliferation in rats. Brain Res 1040: 55-63.

Rossi C, Angelucci A, Costantin L, Braschi C, Mazzantini M, Babbini $\mathrm{F}$ et al (2006). Brain-derived neurotrophic factor (bdnf) is required for the enhancement of hippocampal neurogenesis following environmental enrichment. Eur J Neurosci 24: 1850-1856.

Sairanen M, Lucas G, Ernfors P, Castren M, Castren E (2005). Brain-derived neurotrophic factor and antidepressant drugs have different but coordinated effects on neuronal turnover, proliferation, and survival in the adult dentate gyrus. J Neurosci 25: 1089-1094.

Santarelli L, Saxe M, Gross C, Surget A, Battaglia F, Dulawa S et al (2003). Requirement of hippocampal neurogenesis for the behavioral effects of antidepressants. Science 301: 805-809.

Sapolsky RM (1996). Stress, glucocorticoids, and damage to the nervous system: the current state of confusion. Stress 1: 1-19.

Saxe MD, Battaglia F, Wang JW, Malleret G, David DJ, Monckton JE et al (2006). Ablation of hippocampal neurogenesis impairs contextual fear conditioning and synaptic plasticity in the dentate gyrus. Proc Natl Acad Sci USA 103: 17501-17506.

Scharfman H, Goodman J, Macleod A, Phani S, Antonelli C, Croll S (2005). Increased neurogenesis and the ectopic granule cells after intrahippocampal bdnf infusion in adult rats. Exp Neurol 192: 348-356.

Schloesser RJ, Lehmann M, Martinowich K, Manji HK, Herkenham M (2010). Environmental enrichment requires adult neurogenesis to facilitate the recovery from psychosocial stress. Mol Psychiatry 15: 1152-1163.

Schmidt HD, Duman RS (2010). Peripheral bdnf produces antidepressant-like effects in cellular and behavioral models. Neuropsychopharmacology 35: 2378-2391.

Seki T, Arai Y (1993). Highly polysialylated neural cell adhesion molecule (ncam-h) is expressed by newly generated granule cells in the dentate gyrus of the adult rat. J Neurosci 13: 2351-2358.

Seri B, Garcia-Verdugo JM, McEwen BS, Alvarez-Buylla A (2001). Astrocytes

give rise to new neurons in the adult mammalian hippocampus. J Neurosci 21: 7153-7160.

Shi SS, Shao SH, Yuan BP, Pan F, Li ZL (2010). Acute stress and chronic stress change brain-derived neurotrophic factor (bdnf) and tyrosine kinase-coupled receptor (trkb) expression in both young and aged rat hippocampus. Yonsei Med J 51: 661-671.

Shirayama Y, Chen AC, Nakagawa S, Russell DS, Duman RS (2002). Brain-derived neurotrophic factor produces antidepressant effects in behavioral models of depression. J Neurosci 22: 3251-3261.

Shors TJ, Mathew J, Sisti HM, Edgecomb C, Beckoff S, Dalla C (2007). Neurogenesis and helplessness are mediated by controllability in males but not in females. Biol Psychiatry 62: 487-495.

Silva R, Mesquita AR, Bessa J, Sousa JC, Sotiropoulos I, Leao P et al (2008). Lithium blocks stress-induced changes in depressive-like behavior and hippocampal cell fate: the role of glycogensynthase-kinase-3beta. Neuroscience 152: 656-669.

Simon M, Czeh B, Fuchs E (2005). Age-dependent susceptibility of adult hippocampal cell proliferation to chronic psychosocial stress. Brain Res 1049: 244-248. 
Smith MA, Makino S, Kim SY, Kvetnansky R (1995a). Stress increases brain-derived neurotropic factor messenger ribonucleic acid in the hypothalamus and pituitary. Endocrinology 136: 3743-3750.

Smith MA, Makino S, Kvetnansky R, Post RM (1995b). Stress and glucocorticoids affect the expression of brain-derived neurotrophic factor and neurotrophin-3 mrnas in the hippocampus. J Neurosci 15: 1768-1777.

Snyder JS, Hong NS, McDonald RJ, Wojtowicz JM (2005). A role for adult neurogenesis in spatial long-term memory. Neuroscience 130: 843-852.

Snyder JS, Kee N, Wojtowicz JM (2001). Effects of adult neurogenesis on synaptic plasticity in the rat dentate gyrus. J Neurophysiol 85: 2423-2431.

Snyder JS, Radik R, Wojtowicz JM, Cameron HA (2009). Anatomical gradients of adult neurogenesis and activity: young neurons in the ventral dentate gyrus are activated by water maze training. Hippocampus 19: 360-370.

Sousa N, Lukoyanov NV, Madeira MD, Almeida OF, Paula-Barbosa MM (2000). Reorganization of the morphology of hippocampal neurites and synapses after stress-induced damage correlates with behavioral improvement. Neuroscience 97: 253-266.

Stein MB, Koverola C, Hanna C, Torchia MG, McClarty B (1997). Hippocampal volume in women victimized by childhood sexual abuse. Psychol Med 27: 951-959.

Stockmeier CA, Mahajan GJ, Konick LC, Overholser JC, Jurjus GJ, Meltzer HY et al (2004). Cellular changes in the postmortem hippocampus in major depression. Biol Psychiatry 56: 640-650.

Stranahan AM, Khalil D, Gould E (2006). Social isolation delays the positive effects of running on adult neurogenesis. Nat Neurosci 9: 526-533.

Su XW, Li XY, Banasr M, Duman RS (2009). Eszopiclone and fluoxetine enhance the survival of newborn neurons in the adult rat hippocampus. Int J Neuropsychopharmacol 12: 1421-1428.

Sui Y, Zhang Z, Guo Y, Sun Y, Zhang X, Xie C et al (2009). The function of notch1 signaling was increased in parallel with neurogenesis in rat hippocampus after chronic fluoxetine administration. Biol Pharm Bull 32: 1776-1782.

Sun Y, Jin K, Childs JT, Xie L, Mao XO, Greenberg DA (2006). Vascular endothelial growth factor-b (vegfb) stimulates neurogenesis: evidence from knockout mice and growth factor administration. Dev Biol 289: 329-335.

Surget A, Saxe M, Leman S, Ibarguen-Vargas Y, Chalon S, Griebel $\mathrm{G}$ et al (2008). Drug-dependent requirement of hippocampal neurogenesis in a model of depression and of antidepressant reversal. Biol Psychiatry 64: 293-301.

Taliaz D, Stall N, Dar DE, Zangen A (2010). Knockdown of brainderived neurotrophic factor in specific brain sites precipitates behaviors associated with depression and reduces neurogenesis. Mol Psychiatry 15: 80-92.

Tanapat P, Hastings NB, Rydel TA, Galea LA, Gould E (2001). Exposure to fox odor inhibits cell proliferation in the hippocampus of adult rats via an adrenal hormone-dependent mechanism. J Comp Neurol 437: 496-504.

Tata DA, Anderson BJ (2010). The effects of chronic glucocorticoid exposure on dendritic length, synapse numbers and glial volume in animal models: Implications for hippocampal volume reductions in depression. Physiol Behav 99: 186-193.

Thomas RM, Hotsenpiller G, Peterson DA (2007). Acute psychosocial stress reduces cell survival in adult hippocampal neurogenesis without altering proliferation. J Neurosci 27: 2734-2743.

Thomas RM, Urban JH, Peterson DA (2006). Acute exposure to predator odor elicits a robust increase in corticosterone and a decrease in activity without altering proliferation in the adult rat hippocampus. Exp Neurol 201: 308-315.
Tozuka Y, Fukuda S, Namba T, Seki T, Hisatsune T (2005). Gabaergic excitation promotes neuronal differentiation in adult hippocampal progenitor cells. Neuron 47: 803-815.

Tyler WJ, Pozzo-Miller LD (2001). Bdnf enhances quantal neurotransmitter release and increases the number of docked vesicles at the active zones of hippocampal excitatory synapses. J Neurosci 21: 4249-4258.

Van der Borght K, Meerlo P, Luiten PG, Eggen BJ, Van der Zee EA (2005). Effects of active shock avoidance learning on hippocampal neurogenesis and plasma levels of corticosterone. Behav Brain Res 157: 23-30.

Veena J, Srikumar BN, Raju TR, Shankaranarayana Rao BS (2009). Exposure to enriched environment restores the survival and differentiation of new born cells in the hippocampus and ameliorates depressive symptoms in chronically stressed rats. Neurosci Lett 455: 178-182.

Vollmayr B, Simonis C, Weber S, Gass P, Henn F (2003). Reduced cell proliferation in the dentate gyrus is not correlated with the development of learned helplessness. Biol Psychiatry 54: 1035-1040.

Vyas A, Mitra R, Shankaranarayana Rao BS, Chattarji S (2002). Chronic stress induces contrasting patterns of dendritic remodeling in hippocampal and amygdaloid neurons. J Neurosci 22: 6810-6818.

Vythilingam M, Heim C, Newport J, Miller AH, Anderson E, Bronen $\mathrm{R}$ et al (2002). Childhood trauma associated with smaller hippocampal volume in women with major depression. Am J Psychiatry 159: 2072-2080.

Wakade CG, Mahadik SP, Waller JL, Chiu FC (2002). Atypical neuroleptics stimulate neurogenesis in adult rat brain. J Neurosci Res 69: 72-79.

Wang S, Scott BW, Wojtowicz JM (2000). Heterogenous properties of dentate granule neurons in the adult rat. J Neurobiol 42: 248-257.

Warner-Schmidt JL, Duman RS (2007). Vegf is an essential mediator of the neurogenic and behavioral actions of antidepressants. Proc Natl Acad Sci USA 104: 4647-4652.

Warner-Schmidt JL, Madsen TM, Duman RS (2008). Electroconvulsive seizure restores neurogenesis and hippocampus-dependent fear memory after disruption by irradiation. Eur J Neurosci 27: 1485-1493.

Westenbroek C, Den Boer JA, Veenhuis M, Ter Horst GJ (2004). Chronic stress and social housing differentially affect neurogenesis in male and female rats. Brain Res Bull 64: 303-308.

Wiskott L, Rasch MJ, Kempermann G (2006). A functional hypothesis for adult hippocampal neurogenesis: avoidance of catastrophic interference in the dentate gyrus. Hippocampus 16: 329-343.

Xu H, Chen Z, He J, Haimanot S, Li X, Dyck L et al (2006). Synergetic effects of quetiapine and venlafaxine in preventing the chronic restraint stress-induced decrease in cell proliferation and bdnf expression in rat hippocampus. Hippocampus 16: 551-559.

Xu Y, Ku B, Cui L, Li X, Barish PA, Foster TC et al (2007). Curcumin reverses impaired hippocampal neurogenesis and increases serotonin receptor la mrna and brain-derived neurotrophic factor expression in chronically stressed rats. Brain Res 1162: 9-18.

Yang SZ, Zhang LM, Huang YL, Sun FY (2003). Distribution of flk1 and flt-1 receptors in neonatal and adult rat brains. Anat Rec A Discov Mol Cell Evol Biol 274: 851-856.

Yi SS, Hwang IK, Yoo KY, Park OK, Yu J, Yan B et al (2009). Effects of treadmill exercise on cell proliferation and differentiation in the subgranular zone of the dentate gyrus in a rat model of type ii diabetes. Neurochem Res 34: 1039-1046.

Zhao C, Deng W, Gage FH (2008). Mechanisms and functional implications of adult neurogenesis. Cell 132: 645-660. 